\title{
THE GORGONIAN-OVULID ASSOCIATIONS OF AN INTERTIDAL CORAL COMMUNITY ON PENANG ISLAND, WEST MALAYSIA
}

\section{by}

\author{
EARL Segal. 1)
}

\begin{abstract}
Over parts of the rocky north shore of Penang Island, West Malaysia, and Pulau Tikus, a small island one mile offshore from Penang, coral communities (Gorgonacea, Alcyonacea, Scleractinia) may be found in the turbid inshore waters. These corals are bathed by the waters of the Muda River system on the mainland and by the waters fluxing through extensive mangal along the mainland and around Penang Island. The diverse components of the coral community are truly intertidal being exposed during spring low tides throughout the year.

It appears as though the gorgonians of the coral community are unusual in their diversity and intertidal distributions. So, too, does it appear, are the ovulid gastropods associated with the gorgonians. I will, both orally and visually, described the Penang-Pulau Tikus intertidal coral community, elaborate on the gorgonians.and their associated ovulid snails, and discuss the stresses placed upon the complex by man.
\end{abstract}

1). Biology Department, California State University, Northridge, California, U.S.A. 